\title{
Analysis and Test of The boom Tension in a Tied arch bridge
}

\author{
Jing Xian SHI ${ }^{\mathrm{a}}$, Qing Hua DING ${ }^{\mathrm{b}}$ \\ Oxbridge College, Kunming University of Science and Technology, Kun-Ming 650106Yunnan, China;
}

\begin{abstract}
The boom tension of the tied arch bridge has a great influence on the state of the bridge, which is the key monitoring project in the construction stage. In this paper, a concrete-filled steel tube arch bridge with a span $60 \mathrm{~m}$ is taken as an example. Based on the theoretical analysis of boom tension of tied arch bridge and the test of construction process, the following results are drawn: in the construction stage, the suspender tension is reasonably controlled to achieve the expected goal of the construction period. The cable force in the finished stage basically coincides with the design expectation. When the bridge is completed, the error precision control of boom tension is better, which ensures the safety of the bridge in the operation stage.
\end{abstract}

\section{Theoretical Calculation}

In this paper, a concrete filled steel tube arch bridge with a span $60 \mathrm{~m}$ is taken as an example, The facade arrangement of this tied arch bridge is shown in Figure 1, calculation vector height is $12 \mathrm{~m}$, ratio of rise to span is $1 / 5$, and vertical and horizontal beam system is adopted for bridge deck structure. 10 sets of booms are set in each of the arch ribs, one-end tension, tension at the top of arch rib, the fixed end is arranged at the bottom of the tie beam.

Boom: The whole bundle extrusion cable system of OVM.GJ15-12 steel strand is used. The supporting anchorage is A (fixed end) and B (tension side) set of anchorage for the whole beam of OVM.GJ steel strand,

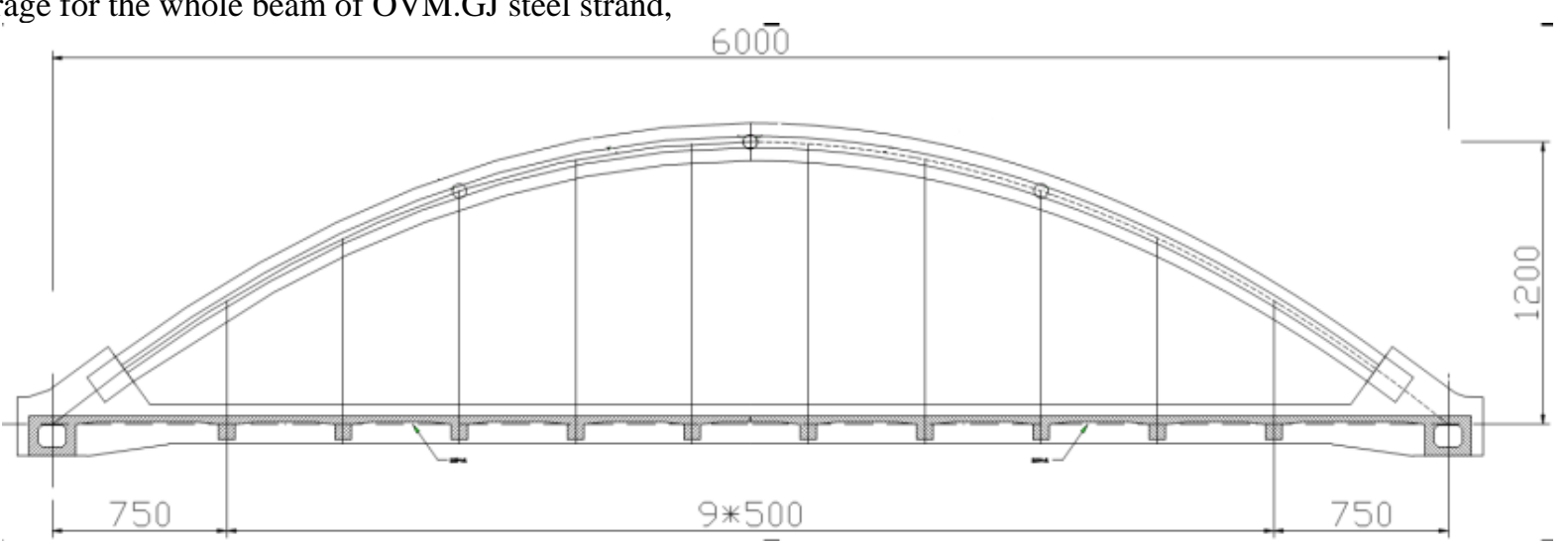

Figure 1 The layout of the main bridge(Unit: cm) the standard strength of the hanger is $\mathrm{f}_{\mathrm{pk}}=1860 \mathrm{MPa}$, and the breaking tensile force is $3125 \mathrm{kN}$. The steel strand is a high strength and low relaxation galvanized steel strand. The outer HDPE jacket of the boom is orange in color.

The theoretical calculation adopts the MIDAS/Civil analysis program and the boom adopts the space truss element (as shown in Figure 2). The boundary conditions are as follows: the bottom hinges of the full framing, hinges at both ends of the arch, the cast-in-place bridge deck unit is consolidated with the tie beam and crossbeam. The material characteristics of the boom in the model are shown in Table 1. 


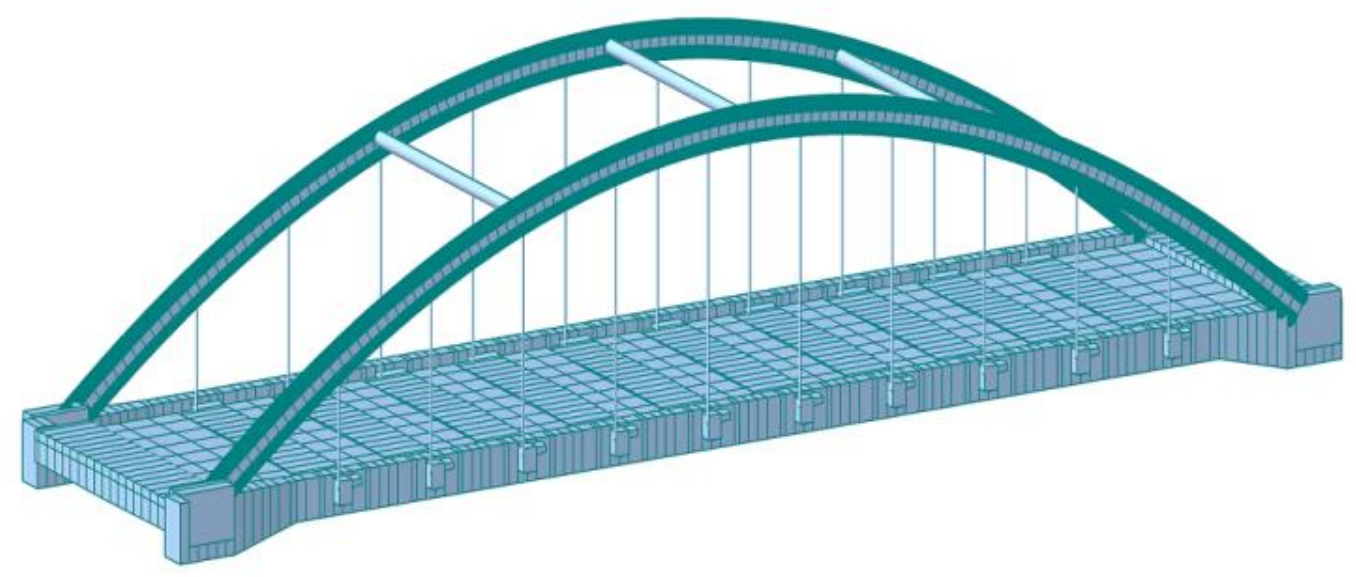

Figure 2 Simplified calculation model of the whole structure

Table 1 The cross section of the boom and the properties of the material

\begin{tabular}{cccccccc}
\hline $\begin{array}{c}\text { Cross section } \\
\text { Area } / \mathbf{m}^{2}\end{array}$ & $\begin{array}{c}\text { Asy } \\
/ \mathbf{m}^{2}\end{array}$ & $\begin{array}{c}\text { Asz } \\
/ \mathbf{m}^{2}\end{array}$ & $\begin{array}{c}\mathbf{C z m} \\
/ \mathbf{m}\end{array}$ & $\begin{array}{c}\text { Material } \\
\text { type }\end{array}$ & $\begin{array}{c}\text { Modulus of } \\
\text { elasticity } / \mathbf{M P a}\end{array}$ & $\begin{array}{c}\text { Bulk density } \\
/ \mathbf{k N} / \mathbf{m}^{3}\end{array}$ & $\begin{array}{c}\text { thermal expansion } \\
\text { coefficient }\end{array}$ \\
\hline 0.0059 & 0.0054 & 0.0054 & 0.0435 & Steel & $1.95 \mathrm{E}+05$ & $7.85 \mathrm{E}+01$ & $1.20 \mathrm{E}-05$
\end{tabular}

Note: Asz-Unit local coordinate system ,Effective Shear Area of Z axis (m2); Czm-The distance between the section of the $-\mathrm{z}$ axis and the edge to the edge fiber along the local coordinate system of the unit $(\mathrm{m})$.

According to the monitoring and calculation results, the maximum cable force in each stage of the whole construction process is shown in Table 2. It can be seen from the table that the safety factor is greater than 4 , which meets the safety requirement of the cable in the construction condition specified by the $<$ Guidelines for Design of Highway Cable-stayed Bridge $>$ (JTG/T D651-2007)3.4.2

Table 2 The calculation result of the boom tension

\begin{tabular}{cccccc}
\hline $\begin{array}{c}\text { Boom } \\
\text { number }\end{array}$ & $\begin{array}{c}\text { Boom } \\
\text { quantity }\end{array}$ & $\begin{array}{c}\text { Sectional } \\
\text { are/mm }\end{array}$ & $\begin{array}{c}\text { Beam end cable } \\
\text { force } / \mathrm{kN}\end{array}$ & $\begin{array}{c}\text { Arch end cable } \\
\text { force } / \mathrm{kN}\end{array}$ & $\begin{array}{c}\text { Safety } \\
\text { factor }\end{array}$ \\
\hline 101 & 2 & 1680 & 572.2 & 572.4 & 5.46 \\
102 & 2 & 1680 & 572.2 & 572.4 & 5.46 \\
201 & 2 & 1680 & 661 & 661.3 & 4.73 \\
202 & 2 & 1680 & 661 & 661.3 & 4.73 \\
301 & 2 & 1680 & 649.8 & 650.2 & 4.81 \\
302 & 2 & 1680 & 649.8 & 650.2 & 4.81 \\
401 & 2 & 1680 & 650.8 & 651.2 & 4.80 \\
402 & 2 & 1680 & 650.8 & 651.2 & 4.80 \\
501 & 2 & 1680 & 666.3 & 666.7 & 4.69 \\
502 & 2 & 1680 & 666.3 & 666.7 & 4.69 \\
\hline
\end{tabular}

\section{Testing Methods and Instruments}

Select the main two construction stages: test the tensioning stage of the boom and the bridge completion stage. The tension stress of suspender is tested by frequency method, that is indirectly testing the transverse vibration frequency of booms, and using the inherent relationship between frequency and tension force to convert the actual cable force. Detailed technical details are based on the following papers: 
- <Singular Perturbation Method for Solving Nonlinear Vibration of Inclined Cables $>$ (Journal of Southwest Jiaotong University,2006);

- $<\mathrm{A}$ New Method to Enhance the Estimation Accuracy of Stay Cable Tension> (Journal of Highway and Technology Research and Development,2007);

- <Singular Perturbation Method for Solving Nonlinear Vibration of Stay Cable(I) - Theory Expressions> (CEBM,2011);

- <Singular Perturbation Method for Solving Nonlinear Vibration of Stay Cable(II) - Engineering Application $>$ (CEBM,2011).

The test instrument using JMM-2681 Cable force measuring instrument, as shown in figure 3.

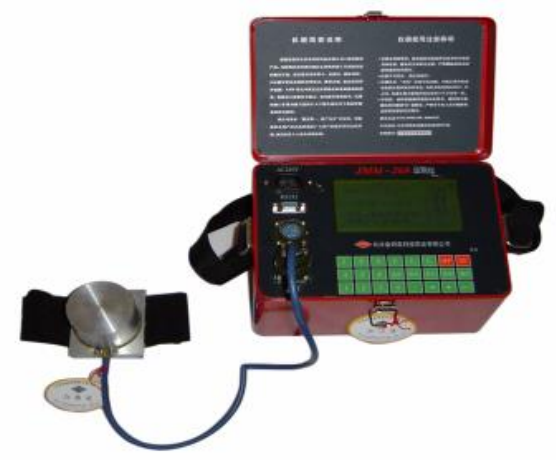

Figure 3. Cable force measuring instrument

\section{Test Result}

The test should meet the following requirements:the accelerometer adopts full seal design, high reliability, super stability, waterproof and moisture proof. The measurement error of cable force is less than $2 \%$. The data acquisition requires an analytical instrument with high sensitivity, which can detect the weak vibration signal of the cable, the built-in charge amplifier, the data acquisition circuit, the automatic shift and zero adjustment, and the 1024 point FFT spectrum analysis. Rely on the measuring instrument to ensure the test accuracy.

When there is a large deviation in the test process, the parameters of the boom need to be identified by the measured data, such as line density, boundary condition correction coefficient, nonlinear correction coefficient and other parameters. The tension test results for the end of the boom and the bridge completion stage are shown in Table 3 and 4.

Table 3 Test result of cable force at completion stage of tensioning boom Unit: $\mathrm{kN}$

\begin{tabular}{lcccccc}
\hline $\begin{array}{c}\text { Point } \\
\text { number }\end{array}$ & $\begin{array}{c}\text { Upper } \\
\text { reaches }\end{array}$ & $\begin{array}{c}\text { Down } \\
\text { stream }\end{array}$ & $\begin{array}{c}\text { average } \\
\text { value }\end{array}$ & $\begin{array}{c}\text { The difference } \\
\text { between the upper and } \\
\text { lower reaches }\end{array}$ & $\begin{array}{c}\text { Theoretical } \\
\text { calculation } \\
\text { value }\end{array}$ & $\begin{array}{c}\text { The difference between } \\
\text { the mean and the } \\
\text { theoretical value }\end{array}$ \\
\hline West 05 & 514 & 521 & 518 & -7 & 497 & 20 \\
West 04 & 503 & 511 & 507 & -8 & 496 & 11 \\
West 03 & 478 & 479 & 478 & -1 & 496 & -17 \\
West 02 & 524 & 504 & 514 & 20 & 495 & 19 \\
West 01 & 505 & 516 & 511 & -11 & 495 & 15 \\
East 01 & 518 & 511 & 515 & 7 & 495 & 19 \\
East 02 & 511 & 518 & 515 & -7 & 495 & 19 \\
East 03 & 485 & 480 & 482 & 5 & 496 & -13 \\
East 04 & 483 & 489 & 486 & -6 & 496 & -10 \\
East 05 & 514 & 504 & 509 & 10 & 497 & 12 \\
\hline
\end{tabular}

Table 4 Test result unit of cable force at completed bridge state Unit: $\mathrm{kN}$

\begin{tabular}{ccccccc}
\hline $\begin{array}{c}\text { Point } \\
\text { number }\end{array}$ & $\begin{array}{c}\text { Upper } \\
\text { reaches }\end{array}$ & $\begin{array}{c}\text { down } \\
\text { stream }\end{array}$ & $\begin{array}{c}\text { average } \\
\text { value }\end{array}$ & $\begin{array}{c}\text { The difference between } \\
\text { the upper and lower } \\
\text { reaches }\end{array}$ & $\begin{array}{c}\text { Theoretical } \\
\text { calculation } \\
\text { value }\end{array}$ & $\begin{array}{c}\text { The difference between } \\
\text { the mean and the } \\
\text { theoretical value }\end{array}$ \\
\hline West 05 & 537 & 547 & 542 & -10 & 559 & -17 \\
West 04 & 638 & 645 & 642 & -7 & 637 & 4 \\
\hline
\end{tabular}




\begin{tabular}{lllllll}
\hline West 03 & 602 & 612 & 607 & -10 & 609 & -2 \\
West 02 & 624 & 637 & 631 & -13 & 615 & 15 \\
West 01 & 641 & 658 & 650 & -17 & 647 & 2 \\
East 01 & 649 & 638 & 644 & 11 & 647 & -4 \\
East 02 & 619 & 638 & 629 & -19 & 615 & 13 \\
East 03 & 621 & 624 & 623 & -3 & 609 & 13 \\
East 04 & 626 & 617 & 622 & 9 & 637 & -16 \\
East 05 & 563 & 572 & 568 & -9 & 559 & 8 \\
\hline
\end{tabular}

\section{Conclusion}

Through the theoretical analysis and construction process test of the boom tension of the tied arch bridge, the following conclusions are drawn:

1)During the construction stage, the control of the boom tension is reasonable and the expected target of the construction period is reached. The boom tension at the completion stage is basically consistent with the design expectation.

2)The error of the boom tension is controlled within $20 \mathrm{kN}$ and the precision is well controlled when the bridge is completed. Such construction control results can ensure the safety of the operation stage of the bridge.

\section{ACKNOWLEDGEMENTS}

Project Source: Yunnan Provincial Department of Education(2017ZZX319)

\section{References}

1. RAN Zhihong,LI Qiao, <Singular Perturbation Method for Solving Non-linear Vibration of Inclined Cables>(Journal of Southwest Jiaotong University, 2006(06).

2. RAN Zhihong, $<$ A New Method to Enhance the Estimation Accuracy of Stay Cable Tension>(Journal of Highway and Technology Research and Development,2007(08).

3. <Singular Perturbation Method for Solving Nonlinear Vibration of Stay Cable(I)-Theory Expressions $>($ CEBM,2011) .

4. <Singular Perturbation Method for Solving Nonlinear Vibration of Stay Cable(II) - Engineering Application>(CEBM,2011).

5. SHI Jing-xian, RAN Zhi-hong. Research on measurement theory of arch bridge suspender tension and error analysis. [J]. Journal of Yunnan University.2012(34)431-437.

6. SHI Chun-xiang,LI Hu-sheng.LIN Li.Practical. solving method and experimental study for short cable tension in consideration of cable stiffness and boundary conditions[J].Journal of Earthquake Engineering and Engineering Vibration,2010,30( 2) : 88-93.
7. SHU Q Z. Research and analysis about the effects of curved bar-tied on arch bridge's structural performance[J].Applied Mechanics and Materials, 2012(6):1567-1570. 